\title{
Unpacking the complex nature of cooperative interactions: case studies of Israeli-Palestinian environmental cooperation in the greater Bethlehem area
}

\author{
Kyra Marie Reynolds
}

Published online: 25 March 2016

(C) The Author(s) 2016. This article is published with open access at Springerlink.com

\begin{abstract}
In the last few decades, a growing number of theorists have suggested that the natural environment can be a platform for promoting cooperation between former adversaries and can perhaps contribute to peacebuilding. However, environmental cooperation has not lived up to these claims. In many cases, such cooperation has largely been ineffective and/or inequitable. Therefore, there is a growing awareness that we cannot be overly optimistic at the first signs of 'cooperation'. It is argued that this reality results from the great complexity inherent in cooperative interactions. This paper explores the nature of such cooperation in two Israeli-Palestinian case studies. The Israeli-Palestinian conflict is one of the longest-running protracted conflicts in the modern era and is currently characterised by a political stalemate. However, there is also a willingness by some at the local level to cooperate. Therefore Israel/Palestine provides an ideal case study. The findings of the paper illuminate the complex nature of environmental cooperation and reveal that even with the presence of good intentions, cooperation at the subnational level is impacted by the broader socio-political structures and contexts within which it is embedded. In these case studies, this is negatively affecting both the nature and scale of the processes and outcomes.
\end{abstract}

K. M. Reynolds ( $\square)$

School of Geography \& Environmental Sciences, Ulster University, Coleraine, County Londonderry, UK

e-mail: reynolds-k4@email.ulster.ac.uk
Ultimately, these factors are making such interactions limited, unstable and/or prone to collapse. The paper concludes that only by conducting in-depth multitiered and context-specific analyses of cooperative processes and subsequently finding ways to overcome the identified barriers can we move towards more successful environmental cooperation.

Keywords Environment - Cooperation · Israel .

Palestine

\section{Introduction}

Alongside concerns pertaining to the emergence of water wars and natural resource conflicts in the $21 \mathrm{st}$ century, the last few decades has witnessed a surge in academic literature expressing the potential of the environment in facilitating cooperation and amicable benefit-sharing between conflicting parties (Phillips et al. 2006). Some even contend that such cooperation can contribute to peacebuilding by spilling over from areas of so-called low-politics (in this case the environment) into areas of high-politics (e.g. Aggestam and Sundell-Eklund 2014). However, despite this optimism, environmental cooperation/peacemaking has not lived up to such expectations and has often been ineffective and/or unfavourable. This paper, recognising this issue as the product of the complexity inherent in the nature and conduct of environmental cooperation, seeks to problematize and unpack this 
complexity. After laying out the literary context to which it contributes, it explores the nature of cooperation in two Israeli-Palestinian cases of environmental cooperation in the greater Bethlehem area. Such exploration, by identifying obstacles and limitations encountered in cooperative interactions, sets the platform for future studies to suggest ways of enhancing the processes and outcomes of such cooperative projects.

\section{Literature review}

Since the mid-1980s, in response to alarmist notions of 'resource wars' and environmentally induced violent conflict that dominated environmental security literature, a more liberal counter-discourse emerged which argued that the environment is more often an inducer of co-operation rather than conflict, and that it could be a potential catalyst for promoting stable relations/peacebuilding (Martin et al. 2011). Indeed, Wolf et al. stated in (2005), that in the previous 50 years, there had been 507 conflict-related transboundary events over water compared to 1228 cooperative events. They contend that "water has...been a productive pathway for building confidence, developing cooperation, and preventing conflict, even in particularly contentious basins" (p. 94). Aside from negotiations and signed agreements, other oft cited evidence of the potential for environmental cooperation has been the formation of transfrontier conservation areas (TFCAs) or 'Peace Parks' (e.g. Ali 2007). Some scholars have thus come to believe that the environment "provides a window of opportunity for cooperation and coexistence between former adversaries" (Coskun 2009: 103). However, these transformative views have been accused of being overly optimistic and of being too hasty with their optimism at the first signs of cooperation. Correspondingly, environmental cooperation literature appears to be becoming increasingly aware that not all cooperation is favourable or effective, thus acknowledging the need to scrutinise the nature of cooperative interactions. These realities, I argue, stem from the complexity inherent in cooperative processes.

Elhance (2000) contends that, "hydropolitics by its very nature is one of the most complex arenas of interstate relations" (p. 202). This stems from the fact that each context brings with it "unique combinations of the geographic features of specific basins with a multiplicity of historical, political, economic, social, strategic and cultural factors" (p. 202). Within this already complicated context, one must add the range of self-interested actors engaged in the cooperation, each coming to the table with their own interests and agendas, political standings, developmental stage, perceptions, power position and reputations (e.g. Victor 2006). In sum, cooperation faces many barriersstrategic, political, technical and economic- that influence the capacity and willingness of actors to engage in cooperative interactions (Elhance 2000). In light of these factors, agreements, conventions, and river basin organisations (RBOs) are not necessarily accurate indicators of cooperation, as is often assumed (e.g. Mirumachi and Allan 2007). They are often nothing more than 'paper tigers', sinks for donor funds, or regimes that preserve or further inequity (Zeitoun 2008), result in asymmetric gains, further economic development under the rubric of promoting cooperation at the expense of the environment (e.g. Sneddon and Fox), and methods which fail to have the presumed spill over effects and thus promote broader cooperation and dialogue at larger political and societal levels (e.g. Carius 2006). In light of these many faces of cooperation, Mirumachi (2007) outlined a 5-level scale which assesses the intensity of cooperation in various cases. These levels are distinguished from one another based on the presence/absence of 4 things: joint action, believing that the other party will contribute to collective action, intention to contribute to collective action, and common goals. This recognises that not all cooperation is of equal value.

It is now also recognised that the presence of cooperative type interactions does not automatically mean the absence of conflict. In fact, cooperation can be laden in conflict (Selby 2013). Zeitoun and Mirumachi (2008) claim that:

The examination of either conflict or cooperation....refutes the reality of the vast majority of contexts where cooperation and conflict coexist, and perpetuates the paradigm that any conflict is 'bad' and that all forms of cooperation are 'good' (p. 297).

The above statement suggests that conflict and cooperation are not necessarily negative and positive respectively. Indeed, they assert that there are "less ugly faces of conflict and less pretty faces of 
cooperation" (p. 299). Yet they claim that these are overlooked, as are the political aspects of these interactions. Cooperation, then, is not always positive. In fact Zeitoun and Mirumachi (2008) claim that it "may serve to veil or perpetuate conflict" and may even "deepen it" (p. 312). A lot of this potential for negative 'cooperation' stems from the fact that it often takes place in situations of highly asymmetrical power and economic relations where the hydro-hegemons can use 'soft power' to achieve their strategic goals at the expense of the hegemonised (Zeitoun and Warner 2006; Mirumachi and Allan 2007). Soft power allows powerful parties to frame inequitable cooperation in a cooperative light (Zeitoun et al. 2011). Hence, Zeitoun and Mirumachi (2008) encourage cooperation theorists not to be too hasty in celebrating the first signs of cooperation without first interrogating the nature of such cooperation. According to Selby (2013), we must ask the following questions when exploring environmental cooperation: "What and whose purposes...does the identification of particular interactions as cooperation serve? And what are the impacts of cooperation discourse, and its attendant practices, on patterns of water inequality, insecurity and vulnerability?" (p. 3). Zeitoun and Mirumachi (2008) point out that the drivers, as well as the power related and strategic features of such interactions, are still underdeveloped within the literature.

The above discussion challenges the previous tendency to think that "it makes sense to promote and support cooperation of any sort no matter how slight" (UNDP 2006, quoted in Selby 2013: 2). At the outset of their volume, Conca (2002) claimed: "We presume that it is not enough just to cooperate; both the form and content of that cooperation are critical" (emphasis added p. 11). By the end of the book, the concluding remarks indicated a consolidation of this assumption:

The case of South Asia provides us with an important caution: ...the mere existence of cooperation is less important than the content, scope, and orientation of that cooperation (Conca and Dabelko 2002: 232).

Zeitoun and Mirumachi's (2008) statement also asserts that cooperation and conflict can occur at the same time. Indeed, Israel/Palestine would appear to be one of those cases in which conflict and cooperation coexist. The conflict in the region is one of the most protracted conflicts of the modern era, characterised by a Jewish settler-colonial project aiming to establish a Jewish national homeland in historic Palestine, thereby creating a long-running conflict with the native Arab inhabitants of the region. Although a peace process began in Oslo in 1993, it subsequently collapsed in 2000 with the eruption of the Al-Aqsa intifada (e.g. Coskun 2009). Since that time, there has been a political stalemate and the conflict continues. However, whilst state-level officials still view water-management as a security issue embedded within 'high politics', at the same time there are local level actors willing to cooperate on such issues (Coskun 2009). The presence of a local willingness to cooperate makes it surprising that previous studies of environmental cooperation have largely looked at state-level cooperative interactions. This ignores the potential contribution to be made by subnational actors. There has been recognition that it is local level cooperation that requires further research to determine whether such efforts can induce cooperation on other political issues or whether they can scale up to the state level (Jägerskog 2003). Moreover, it has been at the intra- rather than inter- state level at which water-related violence has more commonly ensued (e.g. Selby 2003). Therefore, cooperation could make a significant impact at this level.

The Israeli-Palestinian conflict, with its subnational cases of environmental cooperation within a broader context of political conflict, thus provides an ideal region of study for the present paper. Two of the subnational environmental cooperation case studies from the greater Bethlehem region will be explored. Through this analysis, the paper will contribute to this still underdeveloped literature on the nature and complexity of cooperation. It asks which elements of complexity play out in these cases, particularly those which undermine the processes and outcomes of the cooperative interactions (Figs. 1, 2).

\section{The case studies}

Case study 1: EcoPeace/FoEME's good water neighbours (GWN) project in Wadi Fukin \& Tzur Hadassah

The Good Water Neighbours project (henceforth GWN) began in 2001 during the height of the $\mathrm{Al}$ Aqsa (Second) intifada as the flagship project of Friends of the Earth Middle East (now and henceforth 
Fig. 1 Map showing the location of the greater Bethlehem area (labelled here as 'Gush Etzion/West Bethlehem Region') in Israel/Palestine (source: Roseman 2008: 27reproduced with the permission of Ecopeace)

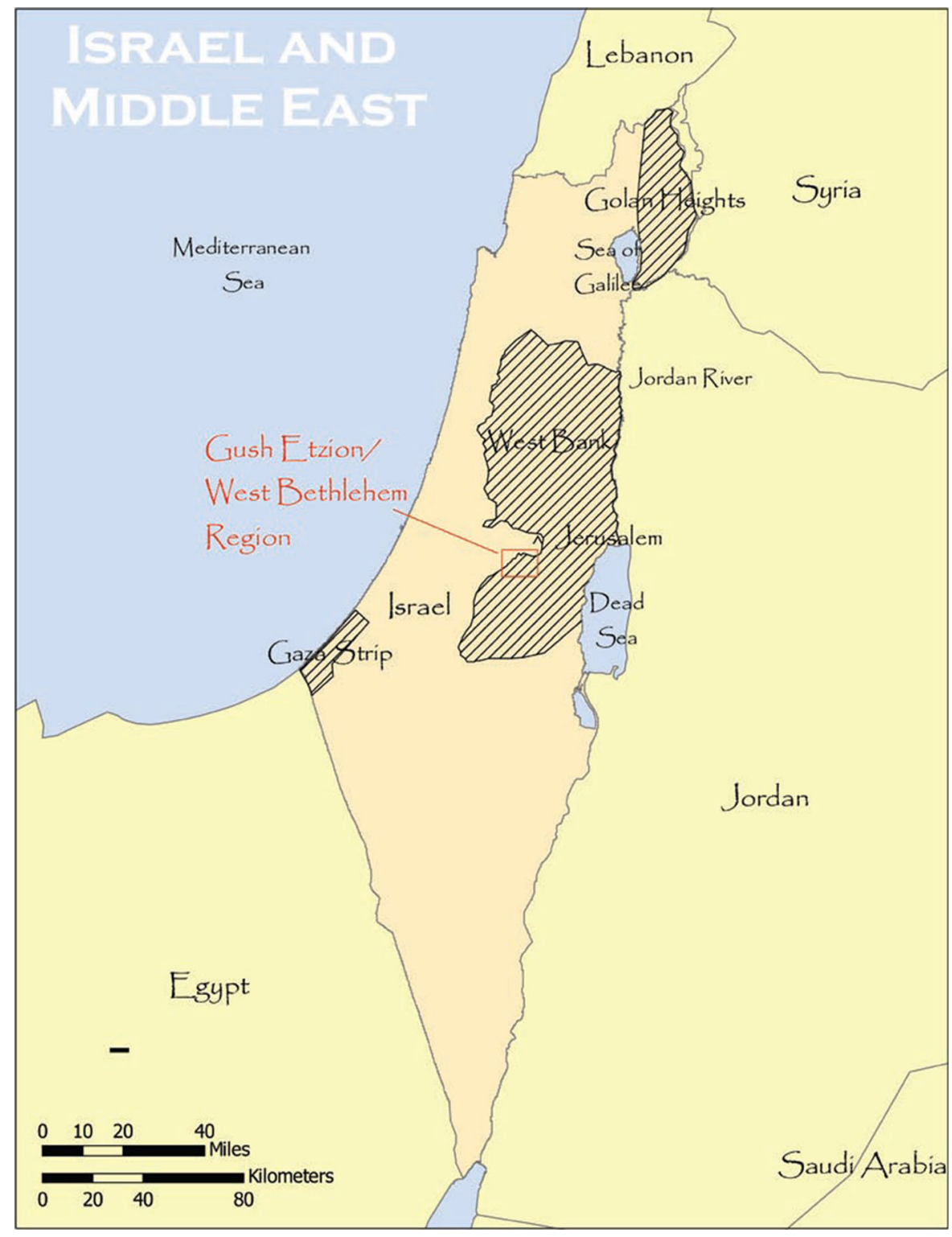

'EcoPeace'). The project, which has leveraged hundreds of millions of dollars, involves the selection of neighbouring communities located on opposite sides of the political divide (Israeli, Palestinian and Jordanian) to cooperate on common water issues. Initially the project included a total of 11 communities but it has since expanded to include 28 . The project is an oftcited example of successful environmental cooperation/peacemaking and has received much praise and attention (e.g. Ide 2014; Kramer 2008; The Butterfly Effect 2014). However, most references to the project have evaluated and analysed it at a general and broad level. Rarely has there been an in depth analysis at the local scale. This ignores the fact that large-scale analysis can paint a very different picture to the reality at smaller scales. This paper therefore focuses on one community pairing- Wadi Fukin and Tzur Hadassah.

The case of Wadi Fukin \& Tzur Hadassah

Wadi Fukin/Foquin/Fuqeen is a small village located $12 \mathrm{~km}$ southwest of Bethlehem and home to approximately 1200 inhabitants (PCBS 2008). The village has faced great adversity since before the 1948 Arab-Israeli 


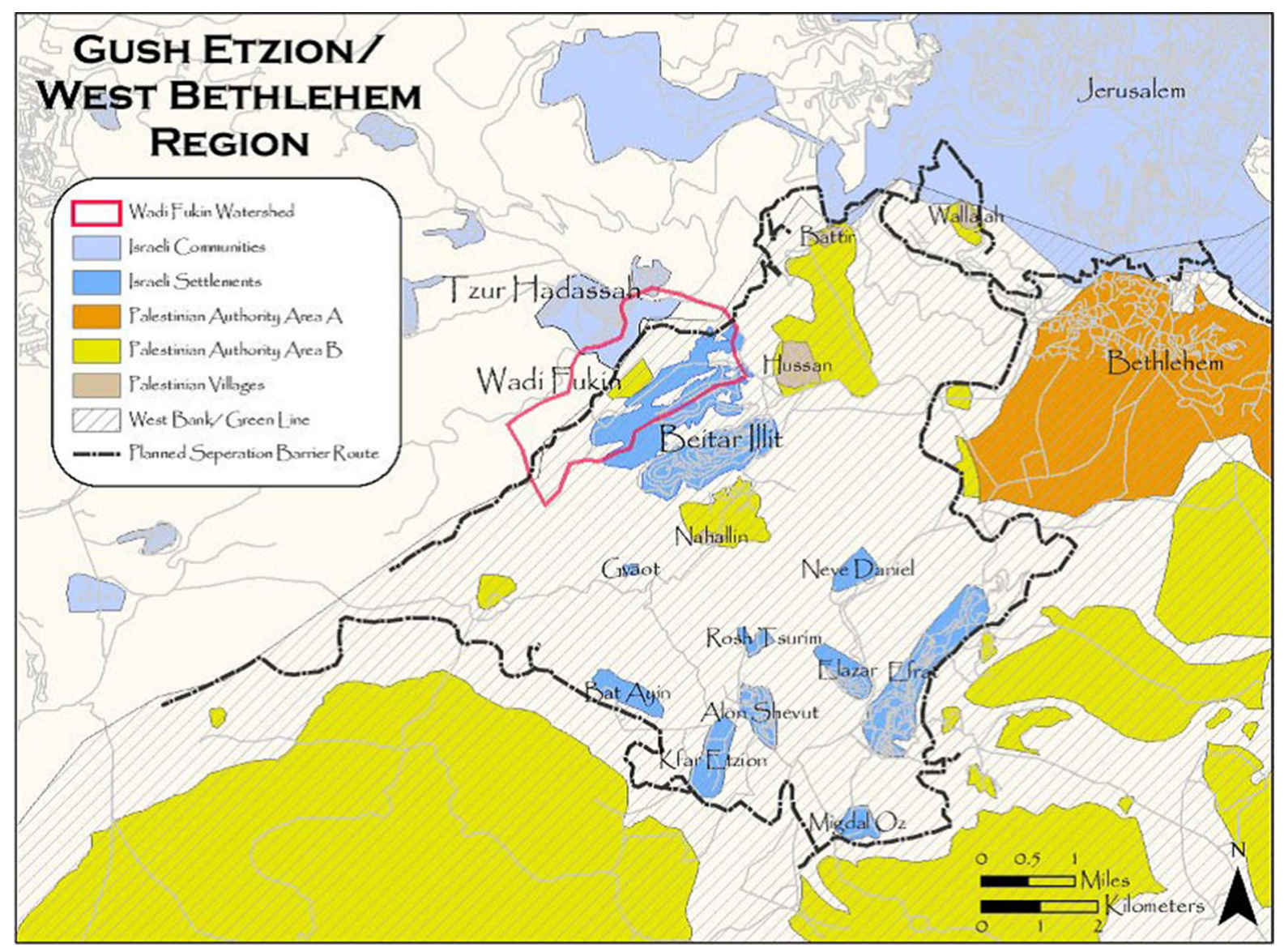

Fig. 2 Map showing the location of the case study communities within the greater Bethlehem area (source: Roseman 2008: 27reproduced with the permission of Ecopeace)

War and has a complex history. It is one of the only Palestinian villages to have been destroyed after 1948 and subsequently rebuilt and resettled by its original inhabitants. Since 1967, the occupation has continued to threaten its existence. The proposed separation barrier, a settler bypass road to the north, and the expansion of the Israeli community of Tzur Hadassah from the west and the Israeli settlement of Beitar Illit from the east, are amongst the factors which threaten to leave the village with just $10 \%$ of its original land (Negotiation Affairs Department, PLO 2006).

Of major concern is the impact these issues are having/could have upon the unique ancient agricultural landscape of the area, which is indigenous to this area of the Judean Mountains (Roseman 2008). In this ancient system, water is channelled from 11 springs through a series of aqueducts to storage pools and eventually to terraced agricultural fields (EcoPeace/
FoEME 2007). For a long time Wadi Fukin served as part of the breadbasket for the Bethlehem area, with agriculture being essential to the livelihoods of its inhabitants. The occupation, however, is impinging upon this landscape and the farming livelihoods it sustains. Since the springs which feed the agricultural lands in Wadi Fukin (the Fukin Springs) also feed the most valuable subterranean freshwater resource in the region, the Mountain Aquifer (which serves both Israelis and Palestinians), preservation of the landscape in the Fukin Valley is also of interest to the neighbouring middle-class Israeli community of Tzur Hadassah (established 1960; population approx. 8000) which lies just west of the Green Line. It is this common interest upon which the GWN project in the area was initiated by EcoPeace.

Wadi Fukin and Tzur Hadassah were amongst the first communities to be paired and incorporated into 
the GWN project in 2001. In line with other GWN communities, the project first engaged the youth by working with schools to provide environmental education programmes, joint trips and a shared summer camp (Roseman 2008). The project then began to focus on the threats at the watershed/regional level, attempting to encourage activism on these issues, amongst them, the expansion of Beitar Illit, sewage overflow from the same settlement, and the proposal to build the separation barrier, all of which threaten to damage the shared water systems. During this phase, EcoPeace began to work with local leaders and adult residents rather than focusing solely on youth. The activities of the GWN project in different areas are geared towards addressing 'Priority Initiatives' that are developed through cross-border meetings between local leaders and consultations with residents in both communities. An Ecopeace representative explained that the idea was to get the communities to talk and identify issues, before asking "what was common?" to them both (Interview, 17th November, 2014). Two priority initiatives have been identified in the case of Wadi Fukin and Tzur Hadassah: 'Cross-Border Preservation of Terraced Landscapes' and 'Advancing Sanitation Solutions' (EcoPeace/FoEME 2013). Activities conducted under the auspices of the GWN project include the creation of a Neighbour's Path in each community which aims to educate members of both communities on their mutual dependence on shared environmental resources, joint hazard mapping tours which identify and map environmental issues and aid in the development of cooperative solutions (EcoPeace/FoEME 2012), as well as joint land use planning for the watershed via workshops involving residents from both communities (these meetings where supplemented by the involvement of the Israeli Society for the Protection of Nature (SPNI) and Israeli planners/architects). The latter culminated in the development of a master plan for the watershed (Roseman 2008). Moreover, some Tzur Hadassah residents learned that the EcoPeace was encouraging sustainable farming techniques (e.g. not using pesticides etc.) in Wadi Fukin. Since then about 25 families from Tzur Hadassah have been buying weekly allotments of the organic produce from Wadi Fukin (Fishkoff 2010). Additionally, Tzur Hadassah residents have also approached numerous Israeli authorities on behalf of their Palestinian neighbours. An example involved an attempt to get Beitar Illit to resolve the issue of sewage flowing from the settlement into the valley. Tzur Hadassah residents have also arranged meetings with the housing ministry in an attempt to stop the development of two new neighbourhoods in Tzur Hadassah within the watershed (Roseman 2008).

Since protecting the landscape of the area has been a key aim of the GWN project in Wadi Fukin and Tzur Hadassah, a major activity of the project has been to challenge the proposed separation barrier. It is the challenge to the barrier which is of particular interest to this article since it is the one which has led to the eventual degradation of cooperative efforts between the two communities. In June 2005, EcoPeace organised a joint tour for residents of the two communities which explored the proposed barrier route. Joint action against the structure ensued. Multiple cross-border meetings to discuss the issue took place (see e.g. Silverman 2010; Wilson 2007) in addition to a joint tree-planting ceremony on the barrier's proposed route (EcoPeace/FoEME 2007). Residents of Tzur Hadassah also conducted a petition at the local mini-market which received 300 signatures from inhabitants of the town. Some Tzur Hadassah residents also went to discuss the barrier with Danny Tirza (head of the military body in charge of planning the barrier's route) (Interview, Tzur Hadassah residents, 5th November, 2014). Furthermore, EcoPeace hired a lawyer and began to prepare a legal challenge. Significantly, the legal challenge did not take the familiar human rights route. Instead, the case was made on environmental grounds. This was the first time a legal challenge to the separation barrier was environmentally based (e.g. Fishkoff 2010). To strengthen the case, three environmental professionals from Tzur Hadassah (an employee of SPNI, a hydrologist and a geologist) prepared two reports, one exploring the impact on the landscape and the other examining the hydrological ramifications (Interview, Tzur Hadassah resident, 5th November, 2014). In the end, according to a representative of EcoPeace, the case did not actually have to go to court and for the meantime the petitioning and campaigning has been successful in halting the construction of the barrier (Interview, 17th November, 2014).

The GWN project in Tzur Hadassah and Wadi Fukin has received much praise including from former U.S. President Jimmy Carter (see Eldar 2009). It has also been deemed an example of how cooperation over 
water issues can spill over into other issues e.g. the separation barrier (e.g. Kramer 2008). Indeed, the author's own interviews revealed that the Israeli activists also took action in attempt to help their Palestinian partners with travel restrictions in relation to medical treatment and employment (Interviews November 5th, 2014; see also Fishkoff 2010). However, when the author visited Wadi Fukin in November 2014 , members of the community who had previously been involved in the GWN project indicated that they would no longer participate. The reason given was the ongoing expansion of Tzur Hadassah onto land adjacent to Wadi Fukin where the separation barrier was planned. One resident stated that "Now I call it [Tzur Hadassah] a settlement because this part is built on the fields of Wadi Fukin" (Interview, 29th November, 2014). He highlighted the disappointment of the GWN activists in Wadi Fukin when they noticed the expansion: "We thought we had been deceived. We felt that they were mainly preparing to have room for the settlement...In general we feel that there is a Zionist plan". He even went as far as to say: "If the wall had been built, it would have been much better" because they would have lost less land. He proceeded to state that cooperation has now stopped and that "recently, if there was anything, it is at the individual level". He claimed that "now, if you mention the name of Tzur Hadassah, the people [of Wadi Fukin] would be angry... people think we [the GWN activists from Wadi Fukin] are making normalization with the settlers" (Interview, 29th November, 2014). How then could this "intimate experiment in cross-cultural cooperation" (Wilson 2007, para 6), that had been hailed a success, go so wrong so quickly? The forthcoming evaluation will hopefully shed some light on this question. First, the second case study will be outlined.

Case study 2: Settler-Palestinian cooperation?the Kfar Etzion Field School

The story of environmental cooperation in the greater Bethlehem region does not end with Israelis and Palestinians cooperating across the Green Line as in the case of Wadi Fukin and Tzur Hadassah. The media has reported that Israeli settlers from the Kfar Etzion Field School have also developed cooperative relations with Palestinians in nearby villages. Once again, one of the issues this apparent cooperation has centred upon is the proposed separation barrier. Objections to the structure have surfaced amongst Israeli settlers residing in the Gush Etzion bloc. Apparently, this has given rise to a "rare coalition" or "unlikely hodgepodge" of Palestinians, settlers, developers and environmentalists, all opposed to the state-sponsored project (Miller 2014, para 4). The environmentalists on the settler side come in the form of the Kfar Etzion Field School (an organisation which conducts field trips and tours that aim to educate Jews on the history and environment of the Judean region). The field school has apparently undertaken numerous activities of cooperation with neighbouring Palestinians to challenge the barrier. For example, on Tu Bishvat, the Jewish new year of the trees, the field school held a conference in Kfar Etzion to discuss their opposition to the separation barrier and invited along a Palestinian guest from Husan, to talk about the impacts that the structure would have upon Palestinian agriculture. A member of the field school said that the same Palestinian guest was also invited to speak on one of the school's tours that aimed to show settlers the consequences of the proposed barrier (Interview, 25th November, 2014; see also Schwartz 2014). Moreover, Yaron Rosenthal (head of the field school) led a successful legal battle between 2004 and 2006 to reroute part of the barrier at Gush Etzion, apparently cooperating with Palestinians from Wadi Fukin in the process (Mandel 2010). In 2010, Rosenthal issued an invitation to all those within the region, Jews, Arabs and Christians to participate in a joint march in the village of Walaje when construction of the barrier began there (Mandel 2010). The field school has also backed the UNESCO designation of the ancient agricultural terraces at Battir as a World Heritage site, in order to avoid what Rosenthal claims would be "tremendous environmental damage" (quoted in Lewis 2014, para 7). Cooperation between Palestinians and the field school has apparently not ended with the separation barrier. Much like in the Wadi FukinTzur Hadassah case, farmers from Wadi Fukin have asked staff of the field school to help them with environmental hazards emanating from the nearby settlement of Beitar Illit. In one of these instances, staff from the field school went to Wadi Fukin to photograph the damage caused by sewage flows from the settlement. Rosenthal then wrote a letter to the environmental representative of the Israeli Civil Administration. His words appear to reflect 
sympathies with the Palestinian farmers and indicate ongoing cooperation and good relations with them:

As one who grew up on a kibbutz whose living is based on agriculture and spent a lot of time working in fields and groves, I understand the farmers' frustration, after they put all their money and energy in sowing and planting and then lost their entire crop because of Betar's negligence...The instructors of Kfar Etzion field school bring thousands of hikers to the village every year, guiding them among the orchards and fields, the springs and ponds in the wadi and enjoying the residents' generous hospitality (quoted in Rinat 2013, para 8).

Unsurprisingly, some media sources have taken interest in this rare case with numerous optimistic headlines and statements emerging from their articles. Schwartz (2014) is one such commentator who sums up this optimism:

[T]his small group of settlers and Palestinians have put aside their stereotypical roles, and come together for an unlikely collaboration against the Israeli government. The same government that promotes settlements, and is building the security barrier to protect settlers from Palestinian attacks, is quite ironically being opposed by settlers who are joining hands with their Palestinian neighbours (para 15).

While it is common to see Jewish Israelis joining Palestinians in their struggles, these Israelis are almost always left wing, non-settlers. This collaboration may very well be the first of its kind - where Jewish settlers and Palestinians are working together for the common cause of opposing the Israeli government (para 16).

Reports on the case have very much painted a picture of settlers and Palestinians cooperating based on a shared love of the environment and a sympathy on the part of the field school towards the concerns of Palestinian farmers. For instance, after speaking with members of the field school and attending one of their conferences, Schwartz (2014) claimed that the organisation's team "believe that just as strong convictions and a fierce love of this land can inspire hatred against the other side, so too can these passions unite people and plant the seeds of peace". It was also claimed that the field school's "main qualms were that the fence would cut through the land of their Palestinian neighbours in Wadi Fukin, Battir and Husan" (para 2). Indeed, in interviews the author had with residents of Tzur Hadassah for the first case study, there seemed to be an agreement that the field school was genuinely concerned from an environmental and human rights stance. One interviewee claimed that Rosenthal is "unusual among settlers", that "[h]e's very sensitive to moral issues" and "wants to avoid human rights violations of the farmers" (Interview, 5th November, 2014). However, this optimism may be misplaced since despite the issuing of invitations to Palestinians to take part in joint actions, the field school has had limited success in persuading them to participate (e.g. Mandel 2010). Where the Palestinians have chosen to engage with the settlers, it appears to only be in order to ask them to do things for them rather than engaging in joint activities. These issues, together with the emerging warnings to avoid taking cooperation at face value and the fact that general settler objections to the barrier in Gush Etzion are based on concerns over limiting settlement expansion, losing areas of the 'promised land', and being left outside Israel (e.g. Mandel 2010; Miller 2014), there is a need for a more in-depth exploration of the nature of this cooperation. The forthcoming section will do this for the two case studies that have just been outlined.

\section{Discussion/evaluation of the nature of cooperation}

By now it should be recognised that there is a need to interrogate the nature of cooperative interactions. As Zeitoun and Mirumachi (2008) point out, the drivers, power-related and strategic features require careful consideration when analysing cooperation. These features shall be discussed for the case studies that have just been outlined. The discussion will then explore the scale of the impacts for the two cases to see if they have made any progress towards the goal of expanding the cooperation horizontally and vertically. Finally the cooperation intensity shall be assessed using the 5-level scale created by Mirumachi (2007).

Drivers, power-related and strategic features

In exploring the drivers, power-related and strategic features, what is essentially being analysed is the 
motives behind the cooperative interactions. The general theory in the literature is that cooperative interactions develop out of common interests, in this case, the environment. However, Victor (2006) challenges such assumptions, arguing that such ideas are built on an "unrealistic vision of politics" (p. 94). He claims that in reality "there is a whole range of interests and objectives [and that] the only area where they are likely to coincide is in avoiding obviously extreme scenarios" (p. 94). This prompts us to ask whether cooperation in the two case studies is really based on genuine common concern for the environment and human rights, as has been depicted in the media.

The first point relating to motives is that it appears to be the already converted or those who are prone to dialogue/already persuaded that are involved in these activities. This lack of 'representativeness' is a common problem with initiatives which bring two conflicting sides together. (e.g. De Vries and $\mathrm{Maoz}$ 2013). Lack of representativeness means that the actors involved don't represent the political mainstream of their communities. Therefore, there is an ideological gap between co-operators and their broader communities that limits their potential as agents of change when they return to those communities. Hence, the scale of cooperation/peacebuilding activities is constrained. One Tzur Hadassah resident put this clearly when he stated "the people who are most involved are people who are more aware of human rights, more conscientious, who identify with the victims" (Interview, 5th November, 2014). Indeed this sentiment was echoed in other interviews with Tzur Hadassah residents when they talked about their areas of employment: "That's what I'm doing in everyday life...educating on democracy and peace" (Interview, 5th November, 2014). Another indicated that their job in a hospital "provided a window to Palestinian life" and presented "a normal bubble in the middle of abnormality" (Interview, 5th November, 2014). Significantly, when asked if the GWN project between the two communities made them like a normal bubble in the middle of the Israeli-Palestinian conflict, it was claimed that it doesn't due to the small minority that are involved. Furthermore, one interviewee claimed that whilst "it really helped to have the backing from an organisation, doing all the administrative things...I would do what I do anyhow" (Interview, 5th November, 2014). Nevertheless, the role of EcoPeace in stimulating this cooperation should not be underestimated as the same resident who made this comment was introduced to the environmental problems underpinning the GWN campaigns during an EcoPeace tour. Another Tzur Hadassah resident, despite working in the arena of peace and democracy, claimed that prior to the GWN project they "didn't have the same relationship with people from the village [of Wadi Fukin]", and she claimed the project was initially greeted with "lots of hesitations on both sides". Significantly, she stated: "I'm not sure I would have the ability to make first contact", adding that "we didn't have information about the situation" (Interview, 5th November, 2014). Again, at the very least, the catalyst role of EcoPeace is clearly evident.

The already persuaded nature of participants can also be seen in the second case study. For example, a member of the main Palestinian family involved in cooperation with the settler field school is also involved in the Heaven's Field Organic Farm project, a small joint settler-Palestinian organic business project that is sponsored by Eretz Shalom (a peace movement promoting dialogue between settlers and Palestinians). Moreover, the same actor is also one of the main stars in an upcoming documentary film entitled 'A Third Way: Settlers and Palestinians as Neighbours'. Furthermore, Yaron Rosenthal, head of the Kfar Etzion field school, as indicated previously (when outlining the second case study), is seemingly somewhat unusual amongst the settler community in his apparent concern for Palestinian human rights. In fact, he also has networks with the settler peace movement Eretz Shalom (see Mandel 2010).

In both case studies, the motivations for the Palestinian actors were based on concern for maintaining and protecting their land and water resources (which they depend on for survival) from threats posed by the occupational regime. Another motivation for the Palestinian actors in the two cases was the strength that Israeli participation brought to their campaigns. In this regard, the Palestinian activists often spoke of how the Israeli activists had the power to influence Israeli decision-makers. Therefore, they ask the Israeli activists to approach Israeli municipalities, authorities etc. on their behalf. This is an interesting reflection of a counter-hegemonic strategy being employed by the weaker party (Palestinian villagers) in the form of strategic cooperation (with sympathetic neighbouring 
Israeli actors) to challenge the hegemons (settlers and Israeli decision-makers) (e.g. Cascão and Zeitoun 2010). Nachum Pachenik of Eretz Shalom, speaking on a possible joint march between the Kfar Etzion field school and Palestinians from Walaje, stated that: "[t]hey [the local Palestinians] understand that our participation would constitute a far more powerful statement than a leftist group taking part in any kind of demonstration against the [security barrier]" (Mandel 2010, para 11). In sum, the Palestinian motivation is clearly to protect their natural resources and their livelihoods, with evidence of some power-related strategic features being employed to achieve this ends.

Now the paper turns to look at the motivations of the Israeli actors. An external evaluation, referring specifically to Tzur Hadassah participants, claimed that the main motivation for these Israelis was to support the rights and livelihoods of their Palestinian neighbours (The Butterfly Effect 2014). Indeed, a resident of Tzur Hadassah recognised and supported the importance of agriculture to his Palestinian neighbours by acknowledging that it is "their way of maintaining ownership of their land" (Interview, 5th November, 2014). Another went to her municipality to try and persuade them to implement an easier bordercrossing process for Palestinian workers. She also acknowledged that the freeze they managed to achieve on the decision of the barrier, whilst good in some regards, must also be hard for "people looking for justice... [because they]...have to wait such a long time" (Interview, 5th November, 2014). The interests of the Israeli and Palestinian parties in case study one could thus be considered closely aligned. However, it should be noted that in the petition circulated by residents of Tzur Hadassah, the 300 signatories had interests which deviated from the common interest discourse of the GWN project. One Tzur Hadassah resident spoke about how the signatories' reasons for signing the petition varied. Whilst indeed "some [were concerned] for environmental issues, [and] others for violation of human rights", others were motivated by concerns that it "would make security worse... [by] creating tension and friction" (Interview, 5th November, 2014). The latter is obviously an issue of selfinterest and fear, and was echoed by some of the Tzur Hadassah GWN activists themselves. One activist, speaking about the tension she believed the barrier would create, claimed that: "The wall doesn't give me any feeling of security... [It] is the opposite of security" (Interview, 5th November, 2014). This fear was also echoed by some of the members of the Kfar Etzion field school in case study two. A member of staff at the field school, referring to the current levels of trouble with their Palestinian neighbours, stated: "[There is] nothing, it's quiet, [but] if [Israelis] say, [we are] building a fence...now they will start to throw a lot of stones etc." He encourages proponents of the barrier to change their minds so that they "don't turn all this area into a big fight". Significantly, he indicated that the argument they use to dissuade settler proponents of the barrier is that the second intifada problem with terrorists has largely been replaced with rockets, a threat which a fence cannot prevent. They claim therefore that in building the fence, the Israeli government is "get[ting] organized for the war they finished, not the next war" (Interview, 25th November, 2014). They also tell barrier proponents that they can have "as many cameras as [they]...want". Apparently, that way they "won't damage the area... and... [will] save money" (Interview, 25th November, 2014).

The field school may also be predisposed to cooperation given their apparent ecological and preservationist stance. Schwartz's (2014) report on the cooperation involving the field school would indicate that this is the case (see section outlining case study two). For example, one representative of the field school when expressing their concern regarding the threat the barrier posed to the unique landscape of the area stated:

Most people at Gush Etzion only look at politics, it's not good...[In] the eyes of the school, it's an important area to preserve... We're not a politics group. We look at it like, we like the nature, we know the history of the area... This is our culture, we can't throw it to the garbage...same for Arabs, it's their culture (Interview, 25th November, 2014).

The rather nationalist discourse held by the field school in relation to the landscape of the area is another point worth mentioning in terms of their motivation to cooperate. One member of staff from the field school spoke of the terraced landscape of the Palestinian villages in the area and said that such landscapes existed all over Israel before the Romans, since the days of Abraham, the Bible and the Second Temple. He claimed that this is what made this 
landscape so important. He also spoke of a site called Sataf where the Jewish National Fund (JNF) is reconstructing such a landscape in order to do everything as it was done in ancient times. On this point, he claimed Palestinians living on these terraced areas "don't know the techniques as good as before" and he stated that the young go to work elsewhere, thereby threatening the future of these landscapes. Moreover, he expressed concern about the threat the barrier poses to the preservation of potential archaeological areas. For instance, he pointed out that the landscape around Battir was the site where the Rebellion of Bar Kochva leader sat. The rebellion finished with big damage for the Jews, but the interviewee claimed that it was a very important period in Israeli history. Significantly, he seemed concerned about the willingness or capacity of Palestinians in the area to deal appropriately with any possible archaeological heritage:

If [they] build [a] fence here, [they] will leave it at the side of the Palestinians. [This is] not a problem... [but they] will dig it and will ruin it...

[We] don't know what they will find... [This is] a famous story for Israel, we want it to be by us.

The preceding points suggest that the interests of the Israeli and Palestinian actors are divergent in some respects, particularly in case study two. However, it is also clear from the discussion so far that the overarching concern for the activists is preservation of the environment, even if the reasons behind wanting to preserve it are different. Therefore, there is still a common broad goal. Notable also is that the Israeli actors in both cases seem to possess a respect for the human rights of their Palestinian neighbours, recognising their right to exist on their lands, and acknowledging the fact that Palestinian culture is bound up in the same landscape as theirs. Significantly, in peace research, it has been indicated that the aim of peace and reconciliation is not about the elimination of difference, but about creating mutual respect, a factor which seems to have been largely achieved in both case studies, at least initially. A few possible exceptions exist amongst the Palestinian parties in the second case study (beyond the one main family mentioned previously) who 'cooperate' only to harness the power afforded by Israeli involvement, whilst still holding on to views that the settlement is illegal and that the intentions of the settler field school are negative. Notably though, this mutual respect also appears to have faded amongst the Palestinian activists at Wadi Fukin since the expansion of Tzur Hadassah following the freezing of the separation barrier project. The activists now refer to Tzur Hadassah as a settlement, suggesting its illegality and lack of a right to exist in light of its encroachment towards Palestinian land. Importantly, many of the Israeli activists expressed discontent with the sprawling of their town. However, because Ecopeace is still unaware of the collapse of the project in the two communities, this has not been communicated to the Palestinian actors who instead assume that the expansion was the goal of their Israeli partners. One Tzur Hadassah activist even suggested that "maybe it was not such a good idea to prevent the barrier in this area" because it leaves Wadi Fukin residents "feeling...that they are surrounded...[and] squeezed between the two Jewish communities" (Beitar Illit and Tzur Hadassah). He claimed that they would like to oppose the construction but at present they have no grounds to do so because "so far, it doesn't go beyond the 67' border" (Interview, 5th November, 2014).

In sum, it would appear that the two case studies consist of actors who all possess the same goal of protecting the environment, whatever their reasons for pursuing this goal may be. Are there any issues with divergent motivations for pursuing that common goal if divergent motivations are deemed a natural part of cooperative interactions? After all, it has been suggested that cooperation is so intimately tied to the existence of conflict that it can only exist where there is a mix of complementary and conflicting interests (Phillips et al. 2006). The answer to this question probably lies in the commonly touted key element for successful cooperation- 'mutual benefits', as well as the essential principle of conflict management- 'do no harm'. In the two cases studies, these two elements have not been fully achieved.

The most obvious case is the expansion of Tzur Hadassah towards Wadi Fukin after the halting of the separation barrier. In another instance, the Kfar Etzion field school were campaigning against the barrier in a forested area. Their petition to the High Court resulted in a new route being drawn up, one which threatened more Palestinian agricultural lands (Matar 2012). The signing of Tzur Hadassah activists' separation barrier petition by some people who were not concerned with the environment or the travails of their Palestinian 
neighbours, and the security argument given to noncooperating Israelis by the Kfar Etzion Field School may also be problematic when it comes to mutual benefits and doing no harm. This is because these elements do not challenge the 'us versus them' rhetoric so engrained into Israel-Palestinian society. At worst, it may further entrench the already deep rooted fear, blame, mistrust and harmful ideologies that pervade the two societies and sustain the conflict. Moreover, the Kfar Etzion field school's narrative surrounding the environment, whilst indicating their love for the landscape they share with their Palestinian neighbours, at times comes close to reinforcing the Zionist eco-imaginary that enforces a greater Israeli claim over the environment and superior environmental sensitivity relative to Palestinians (see Boast 2012). In some respects it also furthers the problematic Israeli discourse that views Palestinians as having a lack of work ethos and of being underdeveloped and incapable (e.g. Gerber 2003). There are ample examples where the environment, in the form of tree planting, the designation of national parks, and the creation of archaeological areas has been used as a means of land confiscation by the Israeli state. The field school thus needs to be careful that their environmental narrative does not facilitate actions which harm their Palestinian neighbours in any way. For example, their concern for archaeology led one member of staff to claim that perhaps a park should be constructed in the area to preserve it. Whilst he believed that "everyone has good things from that" (Interview, 25th November, 2014), the history of Israeli national park designation reveals that this would not be the case should the idea be implemented by those whose intentions are not so well-meaning. Another point to consider under the principle of 'do no harm' is whether cooperation with Israeli settlers legitimizes the presence of the illegal settlements with the Palestinian territories, thereby causing the Palestinians to consent to their own colonization. Selby (2013) claims that the IsraeliPalestinian Joint Water Committee has had such an effect. In order to ensure that this is not the case, the goals and desired outcomes of joint action should be clearly specified and agreed upon by both parties, and the motives of the actors scrutinized. This ensures that only mutually beneficial outcomes result and that the cooperation is based only upon specific issues (in this case, the need to preserve the environment), thereby meaning that the cooperative activities are not an intention to consent to or a means to further a divisive and asymmetrical politics. In peacebuilding literature, Lederach (1997) states: "We should operate on the basis of being acutely aware of the consequences of our aid on local conflicts that we can avoid doing harms and aggravating the conflicts through our otherwise good intentions" (Lederach 1997: 91). He goes further: "Under conditions of structural violence, many people who behave as good citizens and who think of themselves as peace-loving people", may, in line with the theories of Galtung, participate in "settings within which individuals may do enormous amounts of harm to other human beings without ever intending to do so, just [by] performing their regular duties as a job defined in the structure" (Lederach 1997: 7).

By not challenging and in some instances coming close to matching the dividing dominant discourse that reinforces cleavages between Israelis and Palestinians, coupled with unintended non-mutually beneficial outcomes, the two instances of cooperation have not been able to significantly build trust, a factor which is essential to reaching the full potential of cooperation. They have also been affected by the broader societal structures, politics, narratives and ideologies within which they are embedded. This undermines their chances of success, the scale of their impacts, and their peacebuilding potential. The scale of the impacts is an issue to which the paper now turns.

\section{Scale of impact (horizontal and vertical)}

Within the field of environmental cooperation/peacebuilding, it is hoped that cooperation over environmental issues and the realization of mutual benefits will foster a trust that encourages cooperation on broader issues and at larger scales (e.g. Aggestam and Sundell-Eklund 2014; Phillips et al. 2006). That is, it is hoped that the impacts of cooperation will be scale-up both horizontally and vertically.

It has already been noted that the lack of representativeness of the participants inhibits the scale of the impacts. Added to this issue is the fact that the number of people involved is extremely small. A member of EcoPeace acknowledged this by claiming that the numbers involved in the GWN project in Wadi Fukin and Tzur Hadassah are "not thousands... [but rather] a core group of activists" (Interview, 17th November, 2014). This is also highlighted in the words of a Wadi 
Fukin resident: "Not all the residents of Tzur Hadassah are working with us, only about four of them", (Wilson 2007, 'How Do We Trust?' para 15). A resident from Tzur Hadassah estimated that there were about 20 people involved in the cooperation, and that even amongst this minority, "they are not all involved at the same level". She went on to state that most residents of Tzur Hadassah are "indifferent" and "don't want to get involved" (Interview, 5th November, 2014). When interviewing a member of the Kfar Etzion field school, it was clear that the numbers involved were also limited in the second case study, and seemingly even more so than in the first case. Most activities in this second case study were characterised by the involvement of one particular family from the village of Husan.

Related to the small numbers obstacle and also inhibiting the scale of impact of the two case studies is the presence of what is referred to in peacebuilding literature as the 're-entry problem'. The re-entry problem means that the scale of peacebuilding/cooperation impacts is limited because the small number of cooperating actors are unable to challenge the beliefs of the majority (who oppose change) upon return to their communities (e.g. see De Vries and Maoz 2013). Tzur Hadassah activists despite being a minority within their community, stated that: "nobody protested" and "nobody is against it". However, the reentry problem is still clearly evident since they claimed that the majority of their community are "indifferent" and "don't want to get involved" (Interviews, 5th November, 2014). Significantly, the consequences for Palestinians engaging in such cooperative activities is much harsher. Apparently Wadi Fukin is a village "where many view those who work with the Israelis as collaborators... [These people are] often the targets of the armed groups in the Palestinian territories" (Wilson 2007, para 32). This issue stems from the dominant discourses of distrust, siege and threat towards the 'other' that pervade Israeli-Palestinian society. Fröhlich (2012) claims that it is only through counter-discourses (like those of the actors in these case studies) and expanding what is 'sayable' that these conflict discourses can be challenged. The disapproval of non-cooperating Palestinians is therefore a significant obstacle for the cooperative efforts. It discourages increased participation and encourages existing actors to remain quiet about their cooperative work. When talking to Israeli settlers on a tour about the problems Palestinians faced, one Palestinian who cooperates with the Kfar Etzion field school was accused by Palestinian onlookers of being a betrayer and of working with the Israeli secret police (Interview, staff member of the Kfar Etzion Field School, 25th November, 2014; see also Mandel 2010). As mentioned in the outline of case study one, Wadi Fukin GWN activists are accused by members of their own community of making normalization with the settlers. This situation has worsened following the expansion of Tzur Hadassah after the halting of the separation barrier, because it is perceived to reflect the non-cooperating villagers' fears that this was the motive behind Tzur Hadassah activists' opposition to the structure (e.g. Wilson 2007). Whilst it is acknowledged that "[o]f course there is still good people on that side [and]...we appreciate that", Wadi Fukin activists claim that it this is "difficult to explain to the people [of Wadi Fukin]" (Interview, 29th November, 2014). As a result, the already small number of activists in the village has dwindled even further. Many of them no longer want to engage in cooperative activities because they feel betrayed.

As for the horizontal scaling up of activities (i.e. spilling into other issues-political, economic etc.), there are some positive elements in the case of Tzur Hadassah and Wadi Fukin. Some of the Israeli activists have taken actions to help their Palestinian partners with travel restrictions in relation to medical treatment and employment (Interviews November 5th, 2014). As one example, a Tzur Hadassah activist tried to get her council to help with easing the movement restrictions on Palestinian workers in the mornings. However, this idea collapsed with the onset of unrest in Gaza. However, the interviewee intends to try again once the situation calms down (Interview, 5th November 2014). In the second case study, there was no evidence that environmental cooperation has spilled over into other issues.

Ultimately, it seems that in both case studies, the cooperation is characterised by a small number of individuals, who, given their context and perspective, are already predisposed to cooperative tendencies. Indeed, this is probably what has allowed such cooperation to flourish. However, these characteristics also constrain the positive impacts of the cooperation to a very small scale and limit its peacebuilding capacity. Some scholars (e.g. Victor 2006) contend that smaller numbers can be better than larger 
membership due to the complexity added by each actor and the potential for small-scale cooperation to expand and deepen over time. However, these claims refer to the interstate level. Small numbers and nonrepresentativeness are a problem at the community level (as with the present case studies) where the goal is to scale up environmental cooperation/peacebuilding to the larger scales (municipal, governmental and international levels) and into broader spheres (i.e. political, economic and social issues instead of just environmental ones). The re-entry problem is also limiting the potential impacts of the cooperation. Like the previous section, the above discussion illustrates how the larger context of occupation and ethnonationalist conflict inhibits the scaling-up of impacts and therefore the potential success of environmental cooperation between adversaries.

\section{Cooperation intensity}

On Mirumachi's (2007) scale, cooperation intensity is assessed based on the presence or absence of four factors: joint action, common goals, intention to contribute to collective action and a belief that the other party will contribute to collective action (Mirumachi and Allan 2007). The paper has already explored the last three factors, having looked for the presence of common goals, examined the intentions (drivers/motives), and explored the level of trust. It was found that there does seem to be a common broad goal of preserving the environment but with varying reasons for wanting to do so (motives). It was also found that the context of ethno-nationalist conflict and occupation, as well as the inability to uphold the principles of 'mutual benefits' and 'do no harm', means that trust has not been adequately built, and that fear and suspicion prevail. The nature of the activities (corresponding to the joint action element of the cooperation intensity scale) will now be examined so that the cooperation intensity of the cases studies can be determined.

In both cases, many of the joint activities were conducted on a one-off basis (e.g. tours; cross-border meetings; conferences). This makes it difficult to develop sustainable long-term relationships. Indeed, the desire for follow-ups in order to maintain relationships was one element noted by participants in an external evaluation of the GWN project (The Butterfly Effect 2014), and was one of the limitations of the project noted by Kramer (2008). The author was informed in multiple interviews with Tzur Hadassah and Wadi Fukin residents that the GWN project in the area was now over. For example, a resident of Tzur Hadassah spoke of how they now have very little connection with EcoPeace but indicated that they could approach the organisation if they had any problems. Importantly, Tzur Hadassah residents expressed a willingness "to maintain some connection" with their Palestinian neighbours. One resident stated that: "Now because we're not very active, we want to keep the relationship" (Interview, 5th November, 2014). In the case of Wadi Fukin participants, they claimed the project had finished because they were no longer willing to participate in light of the expansion of Tzur Hadassah after the freezing of the separation barrier. When posed to a member of staff at Ecopeace, she was surprised that the Israeli participants thought the project was over and indicated that, officially at least, it was still ongoing. She believed that the issue arises from the lack of funding afforded to adult projects relative to youth projects (Interview, 17th November, 2014). In the case of the Kfar Etzion field school, the organisation is severely constrained in moving beyond one-off activities due to the lack of willingness on behalf of other organisations and local Palestinian populations to work with settlers. A member of the field school claimed that despite the fact that organisations like EcoPeace, SPNI and INPA are working on the same issues, these institutions "don't want to work with us exactly...cause we work at Gush Etzion". He added that they "don't really like us because we live there" and that "they look at us like righters" (Interview, 25th November, 2014).

In both case studies, it must also be noted that most of the 'cooperation' activities were not actually conducted together. For example, whilst, indeed, there were joint meetings, tours, tree planting events etc. between Wadi Fukin and Tzur Hadassah activists over the separation barrier, it was really Ecopeace, supported by Tzur Hadassah activists, who worked on the subsequent legal challenge. Wadi Fukin had its own case submitted independently. In the Kfar Etzion field school-Palestinian case, the joint activities have been even more limited. This is illustrated for instance by Mandel (2010) who stated that "the activities never achieved the magnitude of a joint march" (para 3) and by Rinat (2014) who wrote that "[t]he Kfar Etzion field school has cooperated with the Palestinians for years, albeit with limited success" (para 4). In fact, in 
the second case study, the cooperation has largely been characterised by two separate campaigns operating on the common goal of preventing the separation barrier and its destruction of the landscape, and with very little interaction between the two. In fact, even when the field school has attempted to get the Palestinians to undertake joint actions with them, they have been met with reluctance. One example was the attempts by Yaron Rosenthal to get residents of Walaje to join them in a march against the separation barrier in the area. Yaron approached the founder of the Erez Shalom movement with the hope that he could encourage the Palestinians to participate. However, residents of Walaje were reluctant: "The wording of the invitation, they say, does not note them as equal parties in the struggle. But the deeper problem lies in the embedded suspicion of the settlers' true intentions" (Mandel 2010, para 5). In fact, the suspicions are so deep that the "the residents of Walajeh avoid creating any connection between the two protests [their own and that of the Kfar Etzion field school] and insist on distinguishing their resistance from the settlers'". Again, the mistrust associated with the dominant conflict discourses and their restrictions on cooperative efforts are clearly visible.

Furthermore, a lot of the activities were characterised by the Israeli activists in both case studies approaching their authorities on behalf of their Palestinian neighbours. A Tzur Hadassah resident outlined the situation: "They are asking us for favours. They understand that human rights is important for us and we are happy to help them". She said that "if they [the Palestinians] contact the authorities, no one will do anything" (Interview, 5th November, 2014). She said that, as a result, the residents of Tzur Hadassah often have to contact Beitar Illit, the Ministry of the Environment etc. for their Palestinian neighbours. Another Tzur Hadassah resident summed up the situation by stating that "[t]hey [their Palestinian partners] feel very powerless... and they are" (Interview, 5th November, 2014). According to the Tzur Hadassah activists, the fact that they "keep annoying the different ministers" for their Palestinian neighbours "has a lot to do with the good relations" between the two parties (Interview, 5th November, 2014). The same scenario is also taking place in the second case study, wherein local Palestinians approach the staff at the field school to get them to contact the appropriate authorities when they have problems. As a member of staff at the field school explained, "Yaron [head of the field school] has very good relationships with them [the residents of Wadi Fukin]. They call him when they have problems... [and he] goes to the newspapers, TV, [etc.]". He went on to explain that the Palestinians can't go to the authorities themselves about their concerns because "nobody listens to them" (Interview, 5th November, 2014). A member of staff at EcoPeace, when asked about the power imbalance inherent in such activities, acknowledged its implications but claimed that "in order to get the end result...sometimes you have to work with the system". She went on to state that "mutual benefits were always in the forefront and in the background" (Interview, 5th November, 2014). Obviously, the cooperating actors in the two case studies are constrained by the political context and it is impossible for them to completely change the unequal system within which they are embedded. However, such power-disparities, should the more powerful parties decide to wield ideational power (coercive and bargaining power) in their leadership of activities, could induce willing compliance of the less powerful in meeting the more powerful's interests (Mirumachi and Allan 2007). However, in these case studies the Israeli parties do not appear to have negative intentions. In fact, this represents an example of how the more powerful actors (the Israeli actors) can actually use their relative power advantage to benefit the weaker parties (e.g. see Cascão and Zeitoun 2010). However, these Israelis are weaker in power relative to the Israeli decision-makers they wish to challenge. Therefore, instigating change still ultimately depends upon the latter. Nevertheless, it is argued here that by simply mirroring the structural and power inequalities inherent in the broader society, the two case studies have significantly reduced their potential for peacebuilding, broader forms of cooperation, and sustaining long-term relationships. For example, it is this disparity inherent in the nature of the activities that is largely responsible for the persistent suspicion and distrust held by the Palestinian actors. One Tzur Hadassah resident summed this up by stating: "we [the Israel participants] have the power....It's easier for us to trust them" (Interview, 5th November, 2014).

Now that all of the four necessary factors have been explored, the case studies can now be placed on Mirumachi's (2007) cooperation intensity scale. The five possible levels (growing in intensity respectively) are: confrontation of the issue, ad hoc cooperation, 
technical cooperation, risk-adverting cooperation, risk-averting cooperation and risk-taking cooperation. Confrontation of the issue is where the issue is acknowledged but no joint action is undertaken. In ad hoc interaction, there is joint action but no shared goals. Technical cooperation occurs where there is shared goals but no joint action. In order for cooperation intensity to be risk-averting, there needs to be joint action, shared goals, and a belief that the other party will do as expected. Risk-taking cooperation is an ideal form wherein the parties enter into cooperation without considering the costs and risks associated with doing so. The last two types are considered high-intensity cooperation (Mirumachi and Allan 2007). Based on the above discussion and findings of previous sections of the paper, it seems that the two case studies could only be classed as being at the lower end of this scale. Most of the activities involve one side undertaking action alone (this includes where one side takes action on behalf of the other). Therefore most of the activities can be described as instances of 'confrontation of the issue' or 'technical cooperation'. There were a few activities that were conducted together- particularly in case study one. If it is claimed that the goals are not really aligned (given the noted variance in motives for preserving the environment), these few activities of joint action can be considered as ' ad hoc' cooperation. If it is accepted that there is a common broad goal (despite the differing motivations for pursuing that goal), some of these joint-action activities could be said to be approaching 'riskaverting cooperation'. However, these few activities have collapsed in case study one following the expansion of Tzur Hadassah. In case study two, these instances of joint action have been rare and when they do occur it has really been one Palestinian family who have engaged with the settlers. All considered, the cooperation intensity of the two case studies can be considered low. In order to move towards high intensity cooperation (risk-averting and risk-taking cooperation), the issues of fear, suspicion and mistrust would need to be addressed and the principles of 'mutual benefits' and 'do no harm' upheld.

\section{Conclusion}

After exploring the nature of cooperation in the two greater Bethlehem case studies, the findings reaffirm the notion that we should not be overly optimistic at the first signs of cooperation. The reality was found to be more complex and less positive than depicted in most media sources. It would appear that the actors' intentions are genuine, with both the Israeli and Palestinian parties sharing the same broad common goal of preserving the environment (even though the motivations for wishing to do so might be different). Most parties also seem to possess a mutual respect for the rights of the other. However, the cooperative activities mirror the structural inequalities and power disparities, as well as the deeply engrained conflict discourses, fears, and intragroup pressures and expectations inherent in Israeli-Palestinian society as a whole. These factors have led to cooperation that is limited, unstable and prone to collapse. These findings remind us that such cooperative interactions do not occur in a vacuum but are influenced by their broader socio-political context, in this case, a protracted ethnonational conflict. This supports Mirumachi and Allan's (2007) assertion that the Israeli-Palestinian case is one where the broader political climate has a great impact on water relations. It also supports Elhance's (2000) assertion that where there is larger societal friction, hydro/environmental politics can become entwined with domestic politics, making it difficult to develop cooperation. Calls for a multitiered approach to examining environmental cooperation are also supported by these findings (e.g. Kistin 2007), as are those for context specific analysis (e.g. Elhance 2000).

Also important to note is that whilst the local cooperative efforts often mirror the larger context and structures of which they are a part, the local scale can also offer opportunities that are not available at the larger scales. For example, the case studies confirm that whilst there is an unwillingness to cooperate at the state level in Israel/Palestine, there are local actors willing to engage in environmental cooperation (Coskun 2009). Some actors at this scale possess counter-discourses which can be used to begin to challenge the dominant conflictdiscourses if we can find ways to overcome the barriers to cooperation (Fröhlich 2012). This reiterates the need to escape from the 'territorial trap' and state-centered focus that has characterised such literature to date (Sneddon and Fox 2006). However, the two cases have also shown that since the societal conflict-discourses of fear and mistrust towards the 
other pervade the local sphere, local cooperative efforts must ensure that they uphold the principles of 'do no harm' and 'mutual benefits'. Failure to do so risks perpetuating and even deepening the negative perceptions of the other.

On a broader level, the paper lends support to the argument that it is only by taking a holistic approach to the analysis of environmental cooperation that the factors of complexity at play can be unpacked and the true nature and limitations of the interactions illuminated. This includes examination of the historical, political, economic, cultural, and social elements in river basins (Elhance 2000), as well as all of the factors relating to the actors themselves (agendas, perceptions, power position, reputation, strategies etc.) (Victor 2006; Zeitoun and Mirumachi 2008). The complexity factors at play in the two case studies explored in this paper include: power-play strategizing, asymmetries in power and socio-political influence, conflict discourses, narratives and ideologies, reentry problems, issues of representativeness, a context of ethno-nationalist conflict, and apparent variance in motives. Future studies must therefore conduct detailed multi-tiered examinations of the context and the nature of cooperation (with all the complexity factors that entails) in a multitude of settings so that we can identify barriers and limitations, the identification of which will allow us to take action for moving towards more meaningful, equitable and ultimately successful forms of environmental cooperation. This will ensure that people across the globe do not fall victim to 'less pretty' forms of environmental cooperation.

Acknowledgments Fieldwork for this paper was partially funded by a grant provided by the French Research Center in Jerusalem (Le Centre de recherche français à Jérusalem- CRFJ). The author also wishes to thank Dr. Sara McDowell and the anonymous reviewers for their comments and suggestions on drafts of the article. The author's PhD project is funded by the Department for Employment and Learning (DEL), a Northern Ireland governmental department

\section{Compliance with ethical standards}

Conflict of interest The author declares that there are no conflicts of interest.

Ethical standard The research was approved by the research ethics committee at Ulster University which deemed that it met all of the required ethical principles for a study involving human participants. The principles of informed consent and confidentiality were upheld for all participants.

Open Access This article is distributed under the terms of the Creative Commons Attribution 4.0 International License (http:// creativecommons.org/licenses/by/4.0/), which permits unrestricted use, distribution, and reproduction in any medium, provided you give appropriate credit to the original author(s) and the source, provide a link to the Creative Commons license, and indicate if changes were made.

\section{References}

Aggestam, K., \& Sundell-Eklund, A. (2014). Situating water in peacebuilding: Revisiting the middle east peace process. Water International, 39(1), 10-22. doi:10.1080/02508060. 2013.848313.

Ali, S. H. (Ed.). (2007). Peace parks: Conservation and conflict resolution. USA: Massachusetts Institute of Technology.

Boast, H. (2012). 'Planted over the past': Ideology and Ecology in Israel's National Eco-Imaginary. Green Letters, 16(1), 46-58. doi:10.1080/14688417.2012.10589099.

Carius, A. (2006). Environmental peacebuilding-Environmental cooperation as an instrument of crisis prevention and peacebuilding: Conditions for success and constraints. Adelphi Consult, Berlin. http://www.adelphi.de/files/uploads/andere/ pdf/application/pdf/us_503_-_carius_environmental_peace making_06-07-02.pdf. Accessed March 16, 2015.

Cascão, A. E., \& Zeitoun, M. (2010). Power, hegemony and critical hydropolitics. In A. Earle, A. Jägerskog, \& J. Öjendal (Eds.), Transboundary water management: Principles and practice (pp. 27-42). New York: Earthscan.

Conca, K. (2002). The Case for Environmental Peacemaking. In K. Conca \& G. D. Dabelko (Eds.), Environmental peacemaking (pp. 1-22). Washington, DC: Woodrow Wilson International Center for Scholars.

Conca, K., \& Dabelko, G. D. (Eds.). (2002). Environmental peacemaking. Washington, DC: Woodrow Wilson International Center for Scholars.

Coskun, B. B. (2009). Cooperation over water resources as a tool for desecuritisation: The Israeli-Palestinian environmental NGOs as desecuritising actor. European Journal of Economic and Political Studies, 2(2), 2-97.

De Vries, M., \& Maoz, I. (2013). Tracking for peace: Assessing the effectiveness of track two diplomacy in the IsraeliPalestinian conflict. Dynamics of Asymmetric Conflict: Pathways Toward Terrorism and Genocide, 6(1-3), 62-74. doi:10.1080/17467586.2013.861074.

EcoPeace/FOEME. (2007). Identifying common environmental problems and shared solutions. EcoPeace/FoEME, Amman, Bethlehem \& Tel Aviv. http://foeme.org/uploads/ publications_publ69_1.pdf. Accessed March 16, 2015.

EcoPeace/FoEME. (2012). FoEME cross border meetingHazard tour in the area of Tsur Hadassah and Wadi Fukin. EcoPeace-Friends of the Earth Middle East, 11th January. https://foeme.wordpress.com/2012/01/11/foeme-hazardwadifukin/. Accessed March 16, 2015. 
EcoPeace/FoEME. (2013). Community based problem solving on water issues: Cross-border "priority initiatives" of the good water neighbours project. EcoPeace/FoEME, Amman, Bethlehem \& Tel Aviv. http://foeme.org/uploads/1384189 $1381 \sim \% 5 \mathrm{E} \% 5 \mathrm{E} \sim$ Community_Based_Problem_Solving_ on_Water_Issues_2013.pdf. Accessed March 16, 2015.

Eldar, A. (2009). Israelis, Palestinians work together in bid to solve local water shortage. Haaretz, 27th September. http:// www.haaretz.com/print-edition/features/israelis-palestini ans-work-together-in-bid-to-solve-local-water-shortage-1.7115. Accessed March 16, 2015.

Elhance, A. P. (2000). Hydropolitics: Grounds for despair, reasons for hope. International Negotiation, 5(2), 201-222. doi:10.1163/15718060020848730.

Fishkoff, S. (2010). Palestinian village and Israeli town build rare partnership across line. Jewish Telegraphic Agency, 20th April. http://www.jta.org/2010/04/20/news-opinion/ israel-middle-east/palestinian-village-and-israeli-town-build -rare-partnership-across-line. Accessed March 16, 2015.

Fröhlich, C. J. (2012). Security and discourse: The IsraeliPalestinian water conflict. Conflict, Security \& Development, 12(2), 123-148. doi:10.1080/14678802.2012. 688290.

Gerber, H. (2003). Zionism, Orientalism, and the Palestinians. Journal of Palestine Studies, 33(1), 23-41. doi:10.1525/ jps.2003.33.1.23.

Ide, T. K. (2014). Towards methodological pluralism: An empirical evaluation of research methods for assessing the link between climate change and violent conflict. $\mathrm{PhD}$ Thesis, University of Hamburg. http://d-nb.info/ 1065805802/34. Accessed March 16, 2015.

Jägerskog, A. (2003). Why states cooperate over shared water: The water negotiations in the Jordan River Basin. Department of Water and Environmental Studies, Linköping University, Sweden. http://www.transboundarywaters.orst. edu/publications/abst_docs/related_research/jagerskog2003 .pdf. Accessed June 2, 2015.

Kistin, E. (2007). Trans-boundary cooperation in SADC: From concept to implementation. Paper prepared for the 8th WaterNet/WARFSA/GWP-SA symposium. Lusaka, Zambia, 30 October-3 November 2007. http://www.research gate.net/profile/Elizabeth_Kistin/publication/228654051_ Trans-boundary_Cooperation_in_SADC_From_Concept_ to_Implementation/links/541b0ccb0cf203f155ae79ba.pdf. Accessed June 18, 2015.

Kramer, A. (2008). Regional water cooperation and peacebuilding in the Middle East. Initiative for peacebuilding regional cooperation on environment, economy and natural resource management cluster-regional case study: Middle East. Adelphi Research, Brussels. http://nl.ircwash.org/ sites/default/files/Kramer-2008-Regional.pdf. Accessed June 19, 2015.

Lederach, J. P. (1997). Building peace: Sustainable reconciliation in divided societies. Washington, DC: United States Institute of Peace.

Lewis, R. (2014). UNESCO names West Bank's Battir a protected world heritage site. Al Jazeera America, 23rd June. http://america.aljazeera.com/articles/2014/6/23/unesco-pales tinebattir.html. Accessed March 16, 2015.
Mandel, J. (2010). 'Settlers and palestinians may unite' against wall. Live Leak, 29th April. http://www.liveleak.com/ view?i=4e4_1272530864. Accessed March 16, 2015.

Martin, A., Rutagarama, E., Cascão, A., Gray, M., \& Chhotray, V. (2011). Understanding the co-existence of conflict and cooperation: Transboundary ecosystem management in the Virunga Massif. Journal of Peace Research, 48(5), 621-635. doi:10.1177/0022343311412410.

Matar, H. (2012). The wall, 10 years on-part 9: Dividing landwater, Fauna, Flora. +972 Magazine, 24th June. http:// 972mag.com/the-wall-10-years-on-part-9-dividing-the-landwater-fauna-and-flora/49195/. Accessed March 16, 2015.

Miller, E. (2014). Netanyahu stalling security barrier construction, settler leader claims. The Times of Israel, 6th October. http://www.timesofisrael.com/netanyahu-stalling-securitybarrier-construction-settler-leader-claims/. Accessed March $16,2015$.

Mirumachi, N. (2007). Fluxing relations in water history: Conceptualizing the range of relations in transboundary river basin. Pasts and futures of water: Proceedings from the 5th international water history association conference. Tampere, Finland, 13-17 June 2006.

Mirumachi, N., \& Allan, J. A. (2007). Revisiting transboundary water governance: Power, conflict cooperation and the political economy. In Proceedings from CAIWA international conference on adaptive and integrated water management: Coping with scarcity. Basel, Switzerland, 12-15 November. http://www.newater.uni-osnabrueck.de/caiwa/data/papers\% 20session/F3/CAIWA-FullPaper-MirumachiAllan25Oct07 submitted2.pdf. Accessed March 16, 2015.

Negotiation Affairs Department, PLO. (2006). Grabbing Jerusalem's bread \& water: Betar Illit vs. Wadi Fukin. Negotiation Affairs Department, Palestine Liberation Organisation, 2006. http://www.nad-plo.org/userfiles/file/ case\%20study/NAD-web.pdf. Accessed March 16, 2015.

PCBS. (2008). Population, housing and establishment census 2007: Census final results in the West Bank summary (population and housing). Palestinian Central Bureau of Statistics, Ramallah. http://www.pcbs.gov.ps/Portals/_PCBS/Downloads/book1487.pdf. Accessed March 16, 2015.

Phillips, D., Daoudy, M., \& McCaffrey, S. (2006). Trans-boundary water co-operation as a tool for conflict prevention and broader benefit sharing. Global Development Studies, No. 4. Ministry of Foreign Affairs, Sweden. http://www.csir.co.za/ websource/pt10002/pdf_files/images/media/2006/EGDI_ TBW.pdf. Accessed June 19, 2015.

Rinat, Z. (2013). Israel orders West Bank settlement to stop polluting nearby Palestinian village. Haaretz, 5th February. http://www.haaretz.com/news/diplomacy-defense/israel-orderswest-bank-settlement-to-stop-polluting-nearby-palestinianvillage.premium-1.501466. Accessed March 16, 2015.

Rinat, Z. (2014). Copying Settlers, Palestinians Mark West Bank Hiking Trails. Haaretz, 13th October. http://www. haaretz.com/israel-news/.premium-1.620470. Accessed March 23, 2016.

Roseman, J. (2008). In depth analysis of the Wadi Fukin/Tzur Hadassah Communities. EcoPeace/FoEME, Amman, Bethlehem \& Tel Aviv. http://foeme.org/uploads/ publications_pub193_1.pdf. Accessed March 16, 2015. 
Schwartz, Y. (2014). Palestinians, Israeli Settlers Fight Security Barrier in Nature Area. NBC News, 30th March. http://www. nbcnews.com/news/mideast/palestinians-israeli-settlers-fightsecurity-barrier-nature-area-n66376. Accessed March 16, 2015.

Selby, J. (2003). Water, power and politics in the Middle East: The other Israeli-Palestinian conflict. London: I.B. Tauris.

Selby, J. (2013). Cooperation, domination and colonisation: The Israeli-Palestinian joint water committee. Water Alternatives, 6(1), 1-24.

Silverman, N. (2010). GWN communities Wadi Fuqin and Tzur Hadassah join to oppose separation barrier. EcoPeace - Friends of the Earth Middle East, 8th March. https://foeme.wordpress.com/2010/03/08/wf-th-separationwall-meeting/. Accessed March 16, 2015.

Sneddon, C., \& Fox, C. (2006). Rethinking transboundary waters: A critical hydropolitics of the Mekong Basin. Political Geography, 25(2), 181-202. doi:10.1016/j.polgeo. 2005.11.002.

The Butterfly Effect. (2014). External evaluation- “Good Water Neighbours Project" concluding report of years 20122014. EcoPeace/FoEME, Amman, Bethlehem \& Tel Aviv. http://foeme.org/uploads/GWN_concluding_evaluation_ report_August_2014_FINAL.pdf. Accessed March 16, 2016.

Victor, D. G. (2006). Toward effective international cooperation on climate change: Numbers, interests and institutions. Global Environmental Politics, 6(3), 90-103. doi:10.1162/ glep.2006.6.3.90.
Wilson, S. (2007). Bonded in resistance to the barrier. The Washington Post, 8th June. http://www.washingtonpost. com/wp-dyn/content/article/2007/06/07/AR2007060702588. html. Accessed March 16, 2015.

Wolf, A. T., Kramer, A., Carius, A., \& Dabelko, G. D. (2005). Managing water conflict and cooperation. In E. Assadourian, et al. (Eds.), State of the world 2005: Redefining global security (pp. 80-95). Worldwatch Institute, Washington, DC. http://tbw.geo.orst.edu/publications/abst_ docs/wolf_sow_2005.pdf. Accessed March 16, 2015.

Zeitoun, M. (2008). Not all water cooperation is pretty. New Security Beat, 4th June. http://www.newsecuritybeat.org/ 2008/06/not-all-water-cooperation-is-pretty/. Accessed June 18, 2015.

Zeitoun, M., \& Mirumachi, N. (2008). Transboundary water interaction I: Reconsidering conflict and cooperation. International Environmental Agreements: Politics, Law and Economics, 8(4), 297-316. doi:10.1007/s10784-008-9083-5.

Zeitoun, M., Mirumachi, N., \& Warner, J. (2011). Transboundary water interaction II: The influence of 'soft' power. International Environmental Agreements: Politics, Law and Economics, 11(2), 159-178. doi:10.1007/s10784010-9134-6.

Zeitoun, M., \& Warner, J. (2006). Hydro-hegemony-a framework for analysis of transboundary water conflicts. Water Policy, 8(5), 435-460. doi:10.2166/wp.2006.054. 